\title{
Two decades of mesoscale phenomena on either side of the Strait of Gibraltar
}

\author{
JAVIER DELGADO, JESÚS GARCÍA-LAFUENTE and CRISTINA NARANJO \\ Department of Applied Physics II, University of Málaga, Campus de Excelencia Internacional del Mar (CEI·MAR), Spain. \\ E-mail: jdcabello@uma.es
}

\begin{abstract}
SUMMARY: Mesoscale circulation patterns in the adjacent basins of the Strait of Gibraltar were investigated by means of altimetry data. In the Gulf of Cádiz, the pattern is relatively stable with two gyres: a cyclonic gyre close to the southern Iberian coast and an anticyclonic one on the western side of the Strait of Gibraltar. Both structures are located in the right place to convey the surface circulation towards the Strait and feed the Atlantic inflow. In the Alboran Sea, our results confirm that the western anticyclonic gyre is the most stable feature observed, while the eastern cyclonic gyre is subject to great variability. The mesoscale structures fluctuate at seasonal and interannual frequencies, but they may also undergo great changes in a very short time scale. A simple correlation analysis suggests that changes in the upstream Gulf of Cádiz basin may be transmitted through the Strait of Gibraltar to the Alboran Sea with a time delay of around one week.
\end{abstract}

Keywords: satellite altimetry, mesoscale circulation patterns, seasonal variability, interannual variability, Strait of Gibraltar, Gulf of Cádiz, Alboran Sea.

RESUMEN: Dos déCADAS De fenómenos de mesoescala a uno y otro lado del estrecho de Gibraltar. - Los patrones de circulación de mesoescala en las cuencas adyacentes al Estrecho de Gibraltar han sido investigados por medio de datos de altimetría. En el Golfo de Cádiz, el patrón se mantiene relativamente estable con dos giros, uno ciclónico cerca de la costa sur Ibérica y otro anticiclónico situado frente de la boca occidental del Estrecho de Gibraltar. Ambas estructuras se encuentran en el lugar adecuado para dirigir la circulación superficial hacia el Estrecho, alimentando el flujo de entrada Atlántico. En el mar de Alborán, nuestros resultados confirman que el giro anticiclónico occidental es la característica más estable, mientras el giro oriental aparece como una característica sujeta a una gran variabilidad. Las estructuras de mesoescala fluctúan en las frecuencias estacionales e interanuales, pero también pueden sufrir grandes cambios en escalas de tiempo cortas. Un análisis de correlación simple sugiere que los cambios en la corriente de la cuenca del Golfo de Cádiz se pueden transmitir a través del Estrecho de Gibraltar hasta el mar de Alborán, con un retraso de una semana.

Palabras clave: altimetría por satélite, patrones de circulación de mesoescala, variabilidad estacional, variabilidad interanual, Estrecho de Gibraltar, Golfo de Cádiz, mar de Alborán.

\section{INTRODUCTION}

The Gulf of Cádiz (GoC) sub-basin of the North Atlantic and the Alboran Sea (AS), the westernmost basin of the Mediterranean Sea, are connected by the Strait of Gibraltar (SG). The exchange through the SG induces hydrodynamic features in the downstream basin (the AS) such as the well-known baroclinic anticyclonic gyres and fronts (Lanoix 1974, Tintoré et al. 1991). The circulation in the upstream basin (the $\mathrm{GoC}$ ) is predominantly anticyclonic in spring-summer with some mesoscale meanders (García-Lafuente et al. 2006, Criado-Aldeanueva et al. 2006a). The flow along the continental slope of the Iberian Peninsula that bounds the anticyclonic circulation at its northern edge (Peliz et al. 2007) separates into two branches, one feeding the Atlantic inflow through the SG and the other veering anticyclonically to join the Canary Current in the south of the basin. Changes in this mainly wind-induced large-scale surface circulation are expected to occur driven by the seasonal wind regime associated with the changes in position and 
strength of the atmospheric Azores high (Fiúza 1983). Reversal of the anticyclonic surface circulation has been reported by Criado-Aldeanueva et al. (2009). The AS is the first basin to receive the inflow of Atlantic water from the GoC. The incoming Atlantic Jet $(\mathrm{AJ})$ is responsible for many of the circulation features observed in the Alboran, in particular a meandering current and the persistent Western Alboran Gyre (WAG), an anticyclonic gyre that dominates the circulation of the western AS. The WAG is usually centred at about $4^{\circ} \mathrm{W}$ with surface currents of around $1 \mathrm{~m} / \mathrm{s}$ and a typical size of $100 \mathrm{~km}$ diameter (VargasYáñez et al. 2002, García Lafuente and Delgado 2004, Vélez-Belchí et al. 2005, Flexas et al. 2006); it is the strongest dynamical feature of the whole western Mediterranean mean circulation (Pujol and Larnicol 2005). Further to the east a second, usually less intense, anticyclonic gyre (the Eastern Alboran Gyre, EAG) is often observed. There are few in situ observations of both WAG and EAG occurring at the same time (Viúdez et al. 1996). The two gyres are connected by the AJ.

Satellite-derived products have been often used to depict the surface circulation of the GoC and AS basins. For instance, Vargas et al. (2003) use sea surface temperature (SST) images to characterize the principal modes of surface circulation in the GoC. Stanichny et al. (2005) exploit high resolution SST images to address local wind-driven upwelling along the African coast in the area of the SG. Baldacci et al. (2001) use SST and SeaWiFS images to investigate physical and biological coupling. Inferring circulation from SST through geostrophy implies that surface currents are roughly parallel to isotherms, which in turn implies implicitly that they do not change much over time. Obviously, in areas where isotherms rapidly evolve or where sea surface is locally and/or temporally homothermal, SST is uninformative. Altimetry data avoid this problem but they have other limitations related to the spatial resolution in near-shore areas where altimetry does not work properly. This fact discourages their use in the area of the GoC, SG and AS although there are interesting examples of their application to oceanographic problems. Viúdez et al. (1998a) characterize annual and semi-annual variability of residual sea level in the Alboran Sea from TOPEX/Poseidon and ERS1 altimeter data; Flexas et al. (2006) use sea level anomalies (SLA), SST and CTD data to describe an eastward migration of the WAG; García-Lafuente et al. (2009) and Naranjo et al. (2012) used SLA to explore the possibility of deep water suction in the AS by means of vertical transfer of momentum from the WAG to the underlying Mediterranean water that would acquire the requested energy to ascend over the sills of the SG.

The aim of this paper is to explore the surface variability in the basins surrounding the SG as inferred from satellite altimetry data, exploiting its synopticity and temporal length.

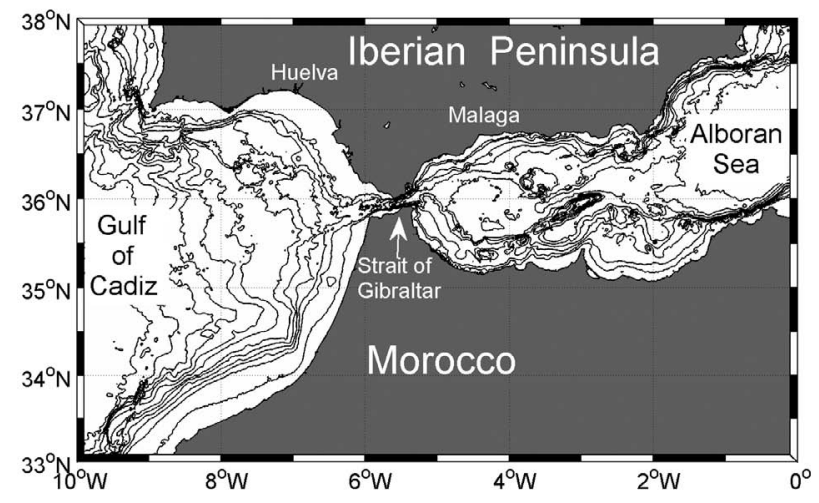

FIG. 1. - Map of the study area showing bathymetric contours of $100,200,600,800,1000,1500,2000,2500$ and $3000 \mathrm{~m}$ and the location of the cities of Huelva and Málaga.

\section{MATERIALS AND METHODS}

Products of altimetry distributed by AVISO (Archiving, Validation and Interpretation of Satellite Oceanographic data) are the data source of this work. In fact, in this study we used not strictly altimetry products but a derived product: delayed-time gridded maps (v3.0.0 of year 2010) of mean absolute dynamic topography (ADT) at level 4. These data are corrected for a large number of phenomena and have been specifically processed for mesoscale studies (filtered from small-scale signals and long wavelength errors; see AVISO handbook for details). The domain is the region bounded by $33-38^{\circ} \mathrm{N}$ and $10-0^{\circ} \mathrm{W}$. Data in the GoC were extracted from the global database with $1 / 3$ degree resolution $(31 \times 31 \mathrm{~km})$ and data in AS come from the Mediterranean database, where specific procedures were applied to obtain a high-quality product of $1 / 8$ degree resolution $(12 \times 12 \mathrm{~km})$. Time resolution is one week and temporal coverage spans from October 1992 to November 2009. Geostrophic velocity $(u, v)$ is also used in this work, being computed from ADT gradients (see AVISO handbook for details). Hourly sea-level height from tide gauges in Huelva (GoC) and Málaga (AS, see Fig. 1) from Puertos del Estado (http://www.puertos.es) were used to compare local sea level with altimetry in order to have a validation of the altimetry data. To carry out this comparison, tidal gauge data were de-tided, filtered (1 week Gaussian low-pass filter) and resampled at altimetry rate (see both processes in Emery and Thomson [1998] for further details). Figure 2 shows that the two datasets agree satisfactorily in the long time scale (seasonal and longer) but differ occasionally in time scales of several weeks (see January 2000 in Huelva and the first part of 2007 at both locations, for instance). Since this study focuses mainly on seasonal and longer scales, these occasional discrepancies are not relevant.

The average behaviour and variability of the system was assessed through the usual mean and standard deviation (std) of ADT. The empirical orthogonal function (EOF) technique was also used to extract the nonseasonal variability, i.e. from sub-seasonal to interan- 


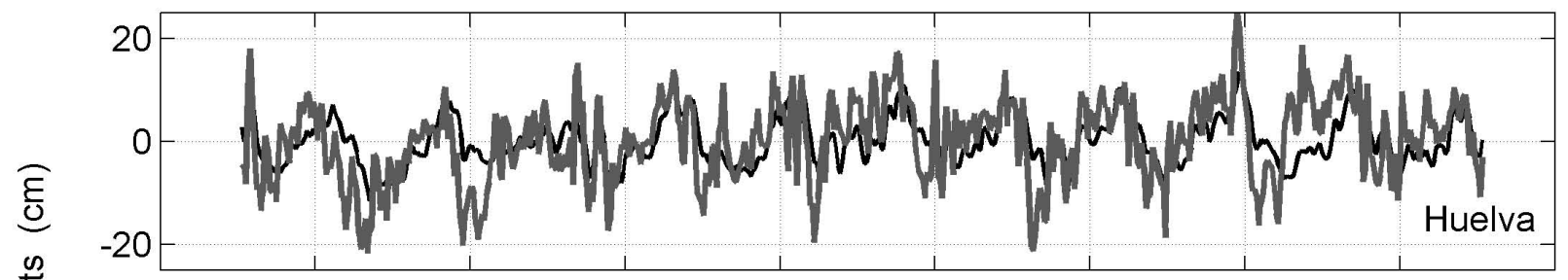

20/04/97 02/09/98 15/01/00 29/05/01 11/10/02 23/02/04 07/07/05 19/11/06 02/04/08 15/08/09

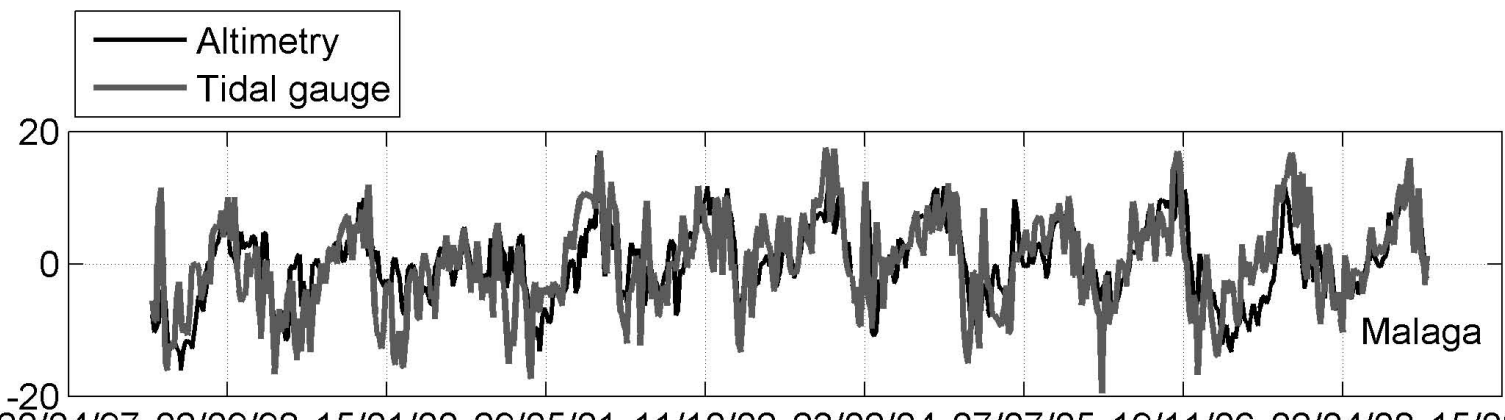

20/04/97 02/09/98 15/01/00 29/05/01 11/10/02 23/02/04 07/07/05 19/11/06 02/04/08 15/08/09

FIg. 2. - Time series of sea level at Huelva (upper panel) and Málaga (lower panel) from tide gauges (grey thick line) and from the altimetry grid points near these locations (black thin line). Temporal mean of each series has been removed. Correlation is $0.56(0.50)$ for Huelva (Málaga).

nual time scales. This standard statistical technique is considered as a very efficient method for extracting the most valuable information from large spatiotemporal datasets (Emery and Thomson 1998). Previously to the use of EOF, the data set was normalized by subtracting the temporal mean and dividing by the std. It is important to note that EOF analysis was applied to the $\mathrm{GoC}$ and AS data sets separately.

\section{RESULTS}

\section{Mean mesoscale structures}

In the $\mathrm{GoC}$, Figure 3a shows an area in the northern part of the domain with ADT values lower than the spatial mean, which indicates cyclonic circulation around Cape San Vicente, that is, southwards flow along the Portuguese coast that veers cyclonically around the cape to head toward the SG. In the centre region, ADT values are above the mean, indicating a large-scale anticyclonic circulation that appears to be more likely a meander than a closed gyre. The ADT differences between these structures give rise to a geostrophic current over the continental shelf-break and slope that points directly to the SG. This feature has been reported previously by several authors (García et al. 2002, García Lafuente et al. 2006, Criado-Aldeanueva et al. 2006a) and appears as the influence of the eastern end of the Azores Current (Peliz et al. 2007). Therefore, a fraction of the surface volume transport in the abovementioned meander is diverted towards the SG to feed the $\mathrm{AJ}$, while the remainder veers southwards to join the Canary Current. The low std values in Figure $3 b$ suggest that these structures are fairly permanent, the changes affecting mainly their extension and position.
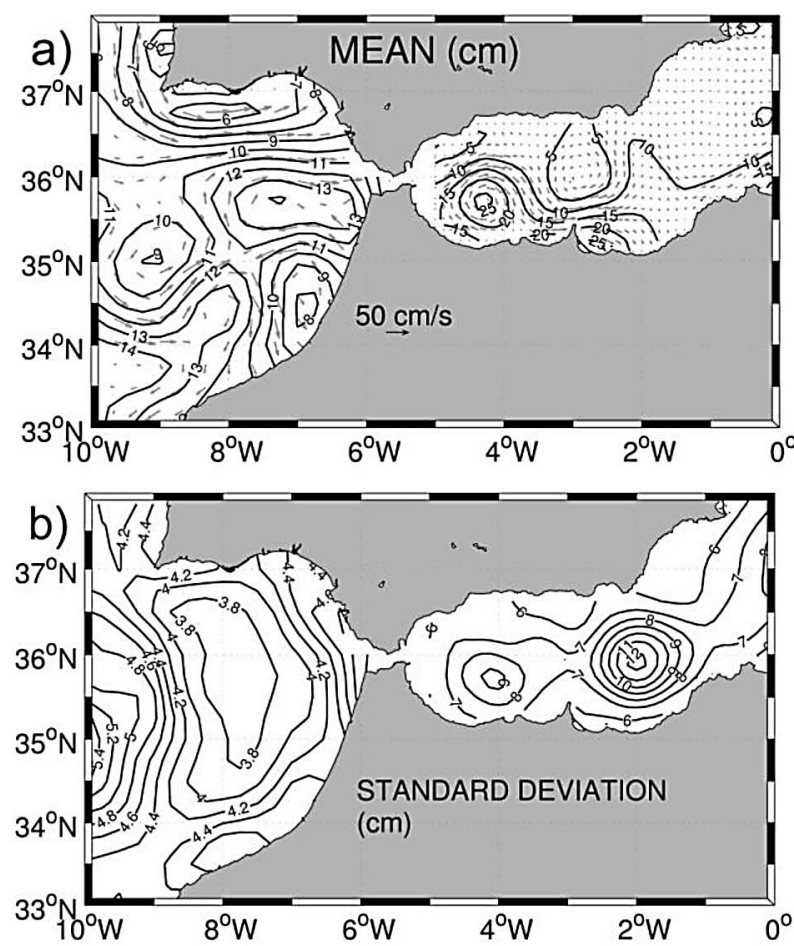

FIG. 3. - a) Spatial distribution of the temporal mean of ADT $(\mathrm{cm})$; vectors show mean geostrophic velocity derived from ADT gradients scaled by the arrow plotted in the inland region. b) Spatial distribution of the ADT std $(\mathrm{cm})$. The contours are interpolated across the area with water; geostrophic flows near solid boundary do not represent the true dynamics.

The mean dynamic topography in the AS shows the AJ following a wave-like path around a welldefined anticyclonic gyre (the WAG) and a meander before leaving the domain on the eastern side 

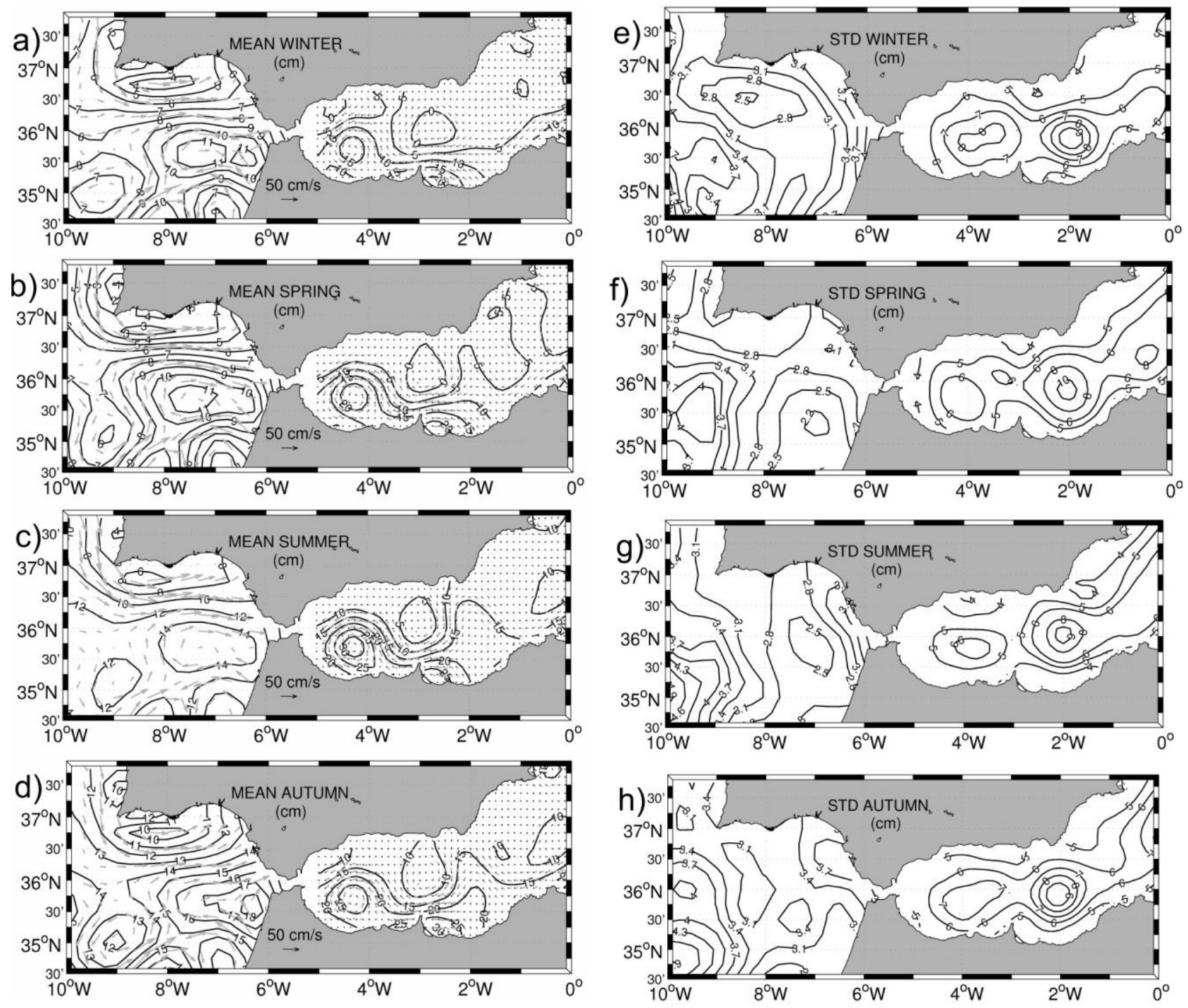

FIG. 4. - Same as Figure 3 for season data subsets, according to the legend at the top of the maps.

attached to the African coast (Fig. 3a). The WAG is a circular structure of $80 \mathrm{~km}$ diameter whose centre is slightly shifted to the southern part of the basin. The std (Fig. 3b) is noticeably smaller than the mean ADT, suggesting that the WAG is a robust feature of the AS circulation. The EAG has not left a clear footprint in mean values; variability in this area is greater than the mean ADT values and the word meander appears to be more appropriate to describe this structure (see Vargas-Yáñez et al. 2002, Flexas et al. 2006). North of the AJ (whose northern edge could be roughly identified by the 10 $\mathrm{cm}$ isoline in Fig. 3a) there is an area of low ADT and also low ADT gradients (low geostrophic velocities) compatible with a weak cyclonic circulation. The variability in this area, as measured by the std (Fig. 3b), is comparable to or even greater than the mean, suggesting poor permanence of these weak structures.

\section{Seasonal variability}

Figure 4 shows the seasonally averaged ADT. The characteristic structures in the $\mathrm{GoC}$ remain basically unchanged despite the steric sea-level cycle. The most noteworthy feature is the seasonal zonal shift of the central anticyclonic area, which moves closer to the SG in autumn (Fig. 4d) and reaches its westernmost position in spring (Fig. 4b). The geostrophic flow towards the SG follows a concomitant seasonal fluctuation with maximum values of 12 to $13 \mathrm{~cm} \mathrm{~s}^{-1}$ in spring-summer and 9 to $10 \mathrm{~cm} \mathrm{~s}^{-1}$ in autumn-winter. The std (Fig. 4 $\mathrm{g}$-h) is almost seasonally independent (slightly greater in autumn), with values of 2.5 to $3.1 \mathrm{~cm}$ in the central part of the basin and higher values near the coast. It is low enough to ensure, on average, the permanency of the structures reported.

The most obvious seasonal variability in the AS is the change in size and strength of the WAG, which 
shows maximum ADT and ADT gradients in summer and minimum ones in winter. The first feature is a consequence of the steric cycle, while the second is probably due to the density contrast between Atlantic and Mediterranean waters (García Lafuente et al. 2002), which gives rise to greater geostrophic velocities in the gyre's periphery in summer $\left(51 \mathrm{~cm} \mathrm{~s}^{-1}\right)$ than in winter $\left(35 \mathrm{~cm} \mathrm{~s}^{-1}\right)$. The std in the WAG area is seasonally independent and small enough to imply the disappearance of the gyre, though it can modulate its size and strength, particularly in winter. Things are different in the eastern Alboran basin. There is no signature of the EAG in winter (Fig. 4e), suggesting that the AJ flows attached to the African coast after leaving the western basin. There are weak signatures in the remaining seasons, which are more visible in summer and autumn when the mean ADT map captures the signature of the Almeria-Oran front (Fig. 4c, d). The main feature in the eastern basin is, however, the large std values, which are large enough to drastically modify the mean pattern. For instance, let us think of an autumn situation (Fig. 4d, h) in which the instantaneous ADT was given by the addition of the mean and the std; under these circumstances, a robust and large EAG would emerge, depicting an intense Almeria-Oran front. On the other hand, a situation in which the actual ADT were given by the mean minus one std would cancel the anticyclonic circulation suggested by the map of the mean (Fig. 4d) and produce a region of cyclonic circulation in the area of the EAG, making the Almeria-Oran front disappear and the AJ flow along the African coast.

\section{EOF analysis}

Time coefficients of EOF analysis are a useful tool for investigating the time variability of the mean patterns of circulation because their associated spatial maps (EOF modes) capture a significant part of the time series variance. Figures $5 \mathrm{a}$ and $5 \mathrm{e}(5 \mathrm{~b}$ and $5 \mathrm{f})$ show that the first mode (second mode) explains 59\% and $66.3 \%(14.2 \%$ and $10.6 \%)$ in the GoC and AS, respectively. These large percentages fulfil the abovementioned condition and support the use of the time coefficient series for analysing the time variability.

The spatial maps of the first EOF in the GoC and AS (Figs. 5a, 5e) recall the patterns in the maps of the means (Fig. 3a) and their associated time coefficients do not depict a clear seasonality, in good agreement with our previous analysis. Time coefficients of mode 2 are more seasonal, suggesting that the weak seasonality found in our previous analysis is mainly captured by this mode, in which case the seasonal nature of the EAG is clearly highlighted in Figure $5 \mathrm{f}$.

Time series are particularly helpful to identify extreme events. Time coefficients of mode 1 in the GoC are always positive (Fig. 5c), which implies the stability of the spatial pattern. However, there are some situations in which the coefficient approaches zero (small circles in Fig. 5c) and the contribution of mode 1 van-
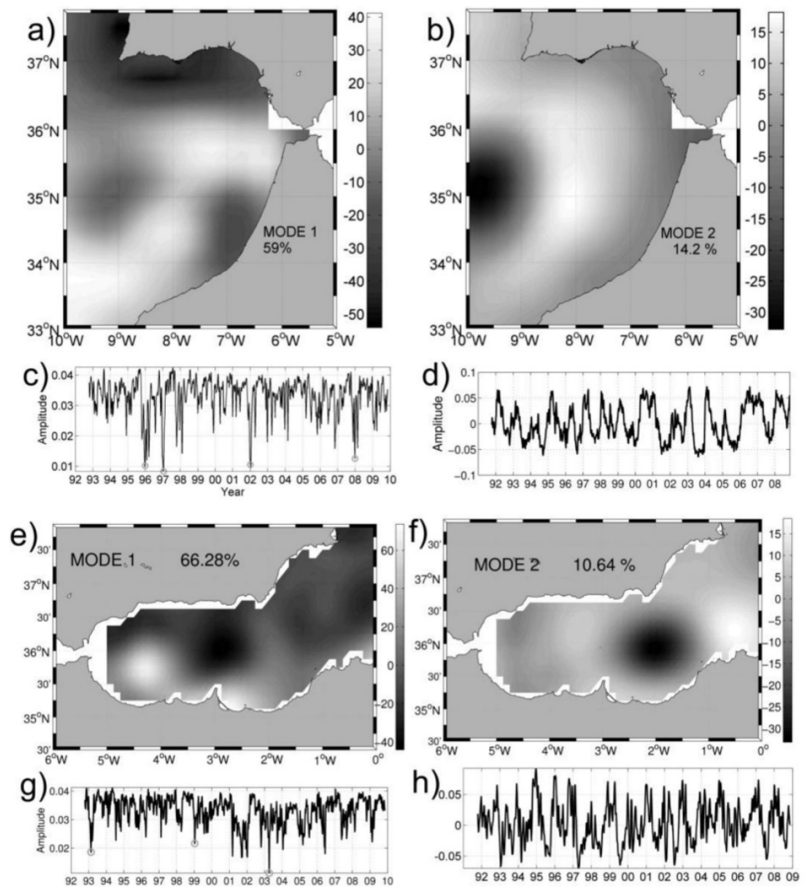

FIG. 5. - a) First and b) second spatial empirical mode in the GoC; c) and d) time coefficients of these modes; e) First and f) second spatial empirical mode in the AS; g) and h) time coefficients. The percentage of variance explained by each mode in either basin is indicated in the spatial maps. The circles in the time series in panels c) and g) mark close-to-zero values of the first mode in GoC and AS, respectively (see text for details).

ishes accordingly. It is then mode 2 that determines the surface circulation. The left panels in Figure 6 show this circulation in the $\mathrm{GoC}$ for the four dates indicated in Figure 5c: the generalized anticyclonic circulation typical of this basin, which is captured by mode 1 , has disappeared and has been replaced by a cyclonic pattern that arises from mode 2 . Their time coefficients are negative on those dates (Fig. 5d), which in turn leaves higher ADT near the shores (Fig. 5b). The final result is the reversal of the surface flow, i.e. an inversion of the continental shelf-break current that now flows from south to north (Fig. 6). Interestingly, these drastic changes are always found in winter months, December in our case, although García Lafuente and Ruiz (2007) reported similar reversals in January. These authors attributed this behaviour to the seasonal, large-scale fluctuation of the atmospheric patterns over the North Atlantic (the Azores high).

The right panels of Figure 6 illustrate three events in the AS during which the contribution of mode 1 is greatly reduced. Again it is mode 2 that determines the surface circulation, which in all cases shows a situation without (panel of 17 February 1993) or with (panels of 13 January 1999 and 17 December 2003) a very weak WAG. In the first case, the AJ flows attached to the African coast from the eastern side of the SG, a situation often known as the coastal mode of the AJ (VargasYáñez et al. 2002) that is most frequently observed in winter months. Other situations would correspond to 

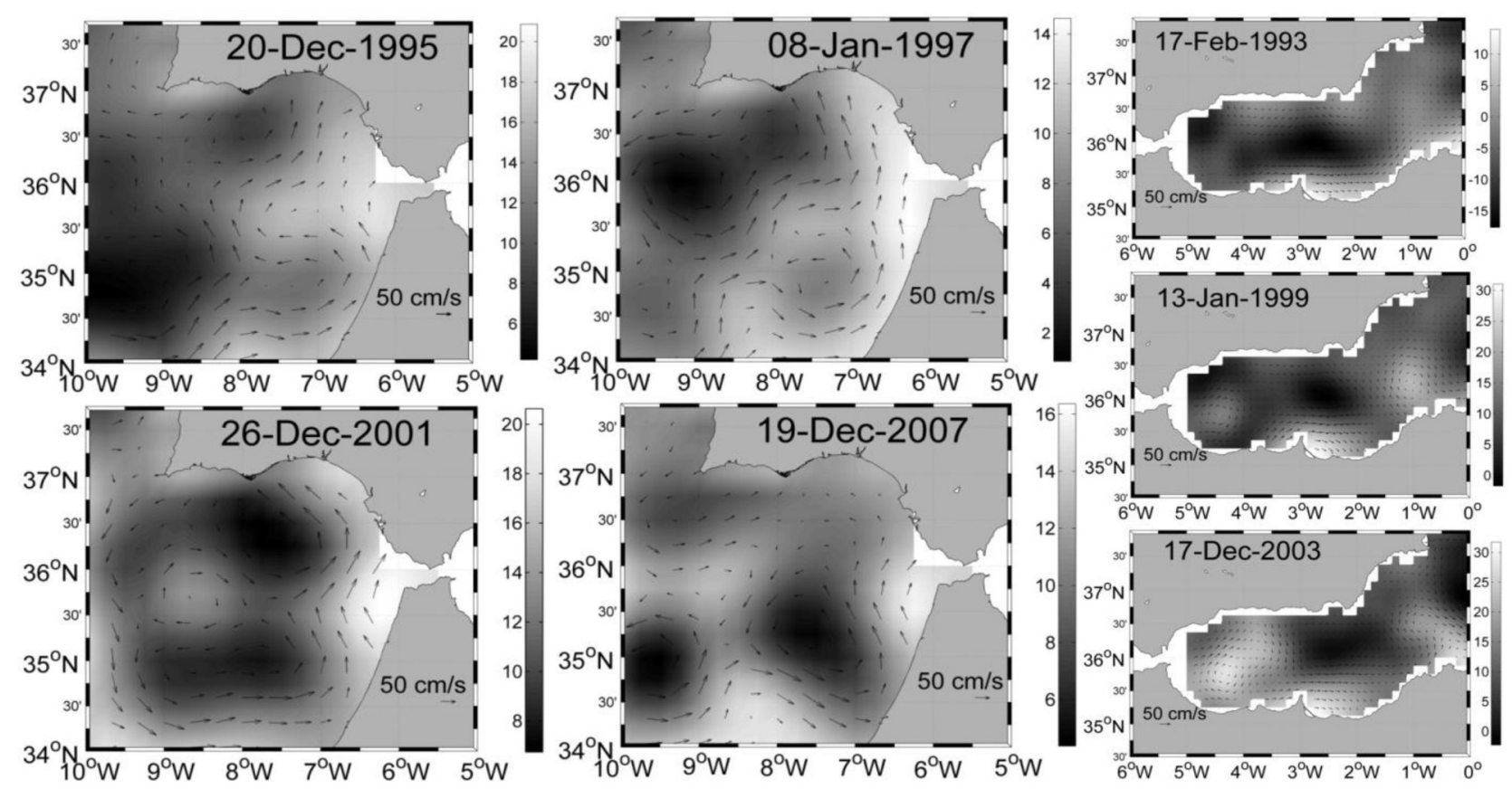

FIG. 6. - Left four panels: ADT and geostrophic currents in the GoC on the dates indicated in the panels, which coincide with the circles in Figure 5c. Right panels: same as above for AS. The dates in this case coincide with the circles in Figure 5g.
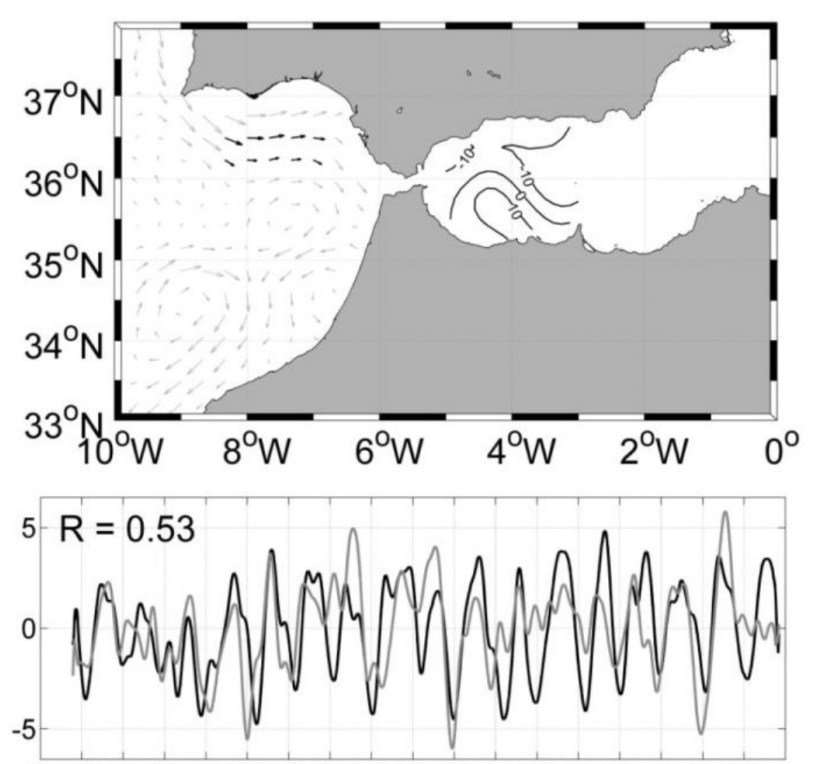

929394959697989900010203040506070809

FIG. 7. - Upper panel: map showing the grid points (black arrows) used to average the velocity used as a proxy of time variability in the GoC. Lower panel: time series of this averaged velocity (black line) represents time series of previous features for GoC and sea level differences for AS (lighter colour), in which fluctuations below two months and their means have been removed. The degree of correlation is 0.53 .

transients during which a new WAG is being formed, a process that takes place in few weeks (Vélez-Belchí et al. 2005), or to the co-existence of three gyres in the basin that migrate eastwards (Viúdez et al. 1998b, Vargas-Yáñez et al. 2002, Flexas et al. 2006).

\section{Correlation of surface structures on both sides of the Strait of Gibraltar}

The SG is too narrow to be observed by altimetry and there is an area around $5.5^{\circ} \mathrm{W}$ without data, which prevents us from connecting directly the two basins by altimetry observations. To investigate possible connections between the two basins, two scalar variables gathering information about the most relevant hydrodynamic mesoscale features of each basin were defined. In the $\mathrm{GoC}$ the best choice is the spatially-averaged velocity in the northern half of the region (black arrows in Fig. 7a) as it is related to the speed of the Atlantic inflow. In the AS the choice was the gradient of the sea surface of the WAG (the height of the centre of the gyre relative to its periphery, in fact). Both time series were smoothed by a low-pass filter of 2 month $^{-1}$ cut-off frequency to remove high frequency and are plotted in Figure $7 \mathrm{~b}$. They are significantly correlated $\left(r^{2}=0.53, P<0.05\right.$, with $r$ being the normalized covariance function and $p$ the $95 \%$ or higher confidence interval) and the correlation increases to 0.56 if the sea-level difference time series is delayed two weeks with regard to the velocity series. As the former represents the surface features of the downstream basin (AS) regarding the surface circulation, and the latter those of the upstream basin $(\mathrm{GoC})$, this delay is interpreted as a cause-effect relationship or, alternatively, as the time-scale required to transmit structure fluctuations through the SG.

\section{DISCUSSION AND CONCLUSIONS}

Seventeen years of merged maps of ADT were used successfully to investigate the most stable surface 
structures in the basins surrounding the SG. Simple and commonly used analysis techniques helped to define the duration and spatial extent of some particular features. The mean ADT in the GoC (Figs. 3 and 4) indicates the presence of a large-scale anticyclonic circulation in the middle of the basin with a northern boundary current flowing over the continental shelfbreak and slope, in agreement with previous studies (Pérez-Rubín et al. 1999, García et al. 2002, CriadoAldeanueva et al. 2006b). This current separates the centre of the gulf from an area of cyclonic circulation off Cape San Vicente in the northern part.

The surface structures have low but distinguishable seasonal variability, with maximum contrast in springsummer and minimum contrast in winter governing a similar cycle in the associated geostrophic velocity. Though weak, this seasonality may have important consequences. For instance, Figure $4 d$ shows the centre of the anticyclonic cell in the $\mathrm{GoC}$ displaced towards the SG and slightly towards the south in autumn. Because this cell helps to convey the Atlantic inflow towards the Strait, this displacement favours the entrance of surface Atlantic water residing in the centre of the GoC into the AS during this season. The enhancement of the cell in spring and its displacement towards the north (Fig. 4b) drains Atlantic water more in the north (i.e. closer to the continental shelf) to feed the inflow. Another consequence of this seasonality is the weakening of the horizontal pressure gradient in winter that facilitates the reversal of the circulation during this season under intense external forcing (see examples in Fig. 6), a situation that agrees with results obtained in previous studies (Vargas et al. 2003, García Lafuente and Ruiz 2007). Although this study does not deal with external forcing explicitly, these drastic changes are surely driven by seasonal changes in the wind regime off the Iberian Peninsula, which veers from northerly in summer (the upwelling season) to westerly or southwesterly in winter (Fiúza et al. 1982, Fiúza 1983), following the seasonal displacement of the Azores high.

In the AS the mean ADT shows the WAG and a meandering AJ as the most stable features. Other usual features such as the Almería-Oran front and the EAG seem to be subject to noticeable seasonal variability. The eastern Alborán basin in particular is the most variable region of the whole domain and the EAG is a very intermittent feature. Sea surface temperature tends to present the EAG as a much more stable feature than was found in this study. As inferred from satellite altimetry data, the EAG is not characterized by a robust pattern of the mean ADT (Fig. 3a and Figs. 4a-d) but by a quite well-defined area of strong variance (see Fig. 3b and Figs. 4e-h).

Finally, the lagged correlation of two derived scalar variables defined in either basin to search for low-frequency connections has provided hints about the propagation of signals from the upper basin $(\mathrm{GoC})$ to the downstream basin (AS). The lagged correlation suggests that two weeks is the time taken by the signal to pass from one basin to the other. This conclusion must be taken with care because this time is close to the time resolution of altimetry time series and further research is needed to clarify the issue. If this cause-effect relationship actually exists, low-frequency time variability of surface structures in the AS will depend on the GoC variability, because the SG is a conduct that allows the signal transmission. Otherwise, the Strait will act as a barrier preventing low frequency signals from being transmitted, and surface structures in both basins will remain isolated from each other.

\section{ACKNOWLEDGEMENTS}

This is contribution $\mathrm{n}^{\circ} 3$ from the CEI.MAR Journal Series. We are grateful to AVISO for the free distribution of the Delayed-Time Regional Altimeter Products by SSALTO/DUACS. The authors wish to thank Puertos del Estado for providing sea-level heights at the Huelva and Málaga stations. Financial support by the Spanish Ministry of Science and Innovation through action CTM2008-04150E and project CTM201021229-C02-01 is also acknowledged.

\section{REFERENCES}

Aviso. 2010. SSALTO/DUACS User Handbook: (M)SLA and (M) ADT Near-Real Time and Delayed Time Products. http://www. aviso.oceanobs.com/fileadmin/documents/data/tools/hdbk_duacs.pdf

Baldacci A., Corsini G., Grasso R., Manzella G., Allen J.T., Cipollini P., Guymer T.H., Snaith H.M. 2001. A study of the Alboran Sea mesoscale system by means of empirical orthogonal function decomposition of satellite data. J. Mar. Syst. 29: 293-311.

Criado-Aldeanueva F., García-Lafuente J., Vargas J.M., Del Río J., Vázquez A., Reul A., Sánchez A. 2006a. Distribution and circulation of water masses in the Gulf of Cadiz from in situ observations. Deep-Sea Res. II 53: 1144-1160.

Criado Aldeanueva F., García Lafuente J. Vargas J.M., Del Río J. Sánchez A., Delgado J., Sánchez J.C. 2006b. Wind induced variability of hydrographic features and water masses distribution in the Gulf of Cadiz (SW Iberia) from in situ data. J. Mar. Syst. 63: 130-140.

Criado-Aldeanueva F., García Lafuente J., Navarro G., Ruiz J. 2009. Seasonal and interannual variability of the surface circulation in the eastern Gulf of Cadiz (SW Iberia). J. Geophys. Res. C 114: C01011.

Emery W.J., Thomson R.E. 2001. Data Analysis Methods in Physical Oceanography. Elsevier Oceanogr. Ser., ed. 2, Amsterdam.

Fiúza A.F.G., de Macedo M.E., Guerreiro M.R. 1982. Climatological space and time variations of the Portuguese coastal upwelling. Oceanol. Acta 5: 31-40.

Fiúza A.F.G. 1983. Upwelling patterns off Portugal. In: Suess E., Thiede J. (eds.), Coastal Upwelling. Plenum, New York, pp. 85-98.

Flexas M.M., Gomis D., Ruiz S., Pascual A., Leon P. 2006. In situ and satellite observations of the eastward migration of the Western Alboran Sea Gyre. Prog. Oceanogr. 70: 486-509.

García C.M., Prieto L., Vargas M., Echevarría F., García Lafuente J., Ruiz J., Rubín P. 2002. Hydrodynamics and the Spatial Distribution of Plankton and TEP in the Gulf of Cádiz (SW OIberian Peninsula). J. Plankton Res. 24: 817-833.

García-Lafuente J., Delgado J., Criado F. 2002. Inflow interruption by meteorological forcing in the Strait of Gibraltar. Geophys. Res. Lett. 29: 1914.

García-Lafuente J., Delgado J. 2004. Meandering path of a drifter around the Western Alboran Gyre. J. Phys. Oceanogr. 34: 685-692.

García-Lafuente J., Delgado J., Criado-Aldeanueva F., Bruno M., 
Del Río J., Vargas J.M. 2006. Water mass circulation on the continental shelf of the Gulf of Cadiz. Deep-Sea Res. II 53: 1182-1197.

Garcia-Lafuente J., Ruiz J. 2007. The Gulf of Cadiz pelagic ecosystem: A review. Prog. Oceanogr. 74: 228-251.

García-Lafuente J., Delgado J., Sánchez Román A., Soto J., Carracedo L., Díaz del Río G. 2009. Interannual variability of the Mediterranean outflow observed in Espartel sill, western Strait of Gibraltar. J. Geophys. Res. 114: C10018.

Lanoix F. 1974. Project Alboran. Étude hydrologique dynamique de la mer d'Alboran. NATO Technical report 66, Brussels, 39 pp.

Naranjo C., García-Lafuente J., Sánchez Garrido J.C., Sánchez Román A., Delgado Cabello J. 2012. The Western Alboran Gyre helps ventilate the Western Mediterranean Deep Water through Gibraltar. Deep-Sea Res. I 63: 157-163.

Peliz A., Dubert J., Marchesiello P., Teles-Machado A. 2007. Surface circulation in the Gulf of Cadiz: Model and mean flow structure. J. Geophys. Res. 112: C11015.

Rubín J.P., Cano N., Prieto L., García C.M., Ruiz J., Echevarría F., Corzo A., Gálvez J.A., Lozano F., Alonso Santos J.C., Escánez J., Juarez A., Zabala L., Hernández F., García Lafuente J., Vargas M. 1999. La estructura del ecosistema pelágico en relación con las condiciones oceanográficas y topográficas en el Golfo de Cádiz, Estrecho de Gibraltar y Mar de Alborán (sector noroeste) en Julio de 1995. Inf. Téc. Inst. Esp. Oceanogr. 175. in Spanish, 73 pp.

Pujol M.I., Larnicol G. 2005. Mediterranean sea eddy kinetic energy variability from 11 years of altimetric data. J. Mar. Syst. 58: 121-142.
Stanichny, S., Tigny V., Stanichnaya R., Djenidi S. 2005. Wind driven upwelling along the African coast of the Strait of Gibraltar. Geophys. Res. Lett. 32: L04604.

Tintoré J., Gomis D., Alonso S., Parrilla G. 1991. Mesoscale dynamics and vertical motion in the Alboran Sea. J. Phys. Oceanogr. 21: 811-823.

Vargas J.M., García-Lafuente J., Delgado J., Criado F. 2003. Seasonal and wind-induced variability of sea surface temperature patterns in the GoC. J. Mar. Syst. 38: 205-219.

Vargas-Yáñez M., Plaza F., García-Lafuente J., Sarhan T., Vargas J.M., Vélez-Belchi P. 2002. About the seasonal variability of the Alboran Sea circulation. J. Mar. Syst. 35: 229-248.

Vélez-Belchi P., Vargas-Yáñez M., Tintoré J. 2005. Observation of a western Alborán gyre migration event. Prog. Oceanogr. 66: 190-210.

Viúdez, A., Tintore J., Haney R. 1996. Circulation in the Alboran Sea as determined by quasi-synoptic hydrographic observations. Part I: Three-dimensional structure of the two anticyclonic gyres. J. Phys. Oceanogr. 26: 684-705.

Viúdez A., Haney R.L., Vázquez-Cuervo J. 1998a. The deflection and division of an oceanic baroclinic jet by a coastal boundary: a case study in the Alboran Sea. J. Phys. Oceanogr. 28: 289-308.

Viúdez A., Pinot J.-M., Haney R.L. 1998b. On the upper layer circulation in the Alboran Sea. J. Geophys Res. 103: 21653-21666.

Received March 10, 2011. Accepted September 4, 2011.

Published online August 3, 2012. 